\title{
PEMANFAATAN APBS DAN GEOGEBRA UNTUK MENINGKATKAN MINAT DAN HASIL BELAJAR MATEMATIKA DI SMP
}

\author{
Kucisti Ike Retnaningtyas Suryo Putro
}

SMP Negeri 12 Surakarta

Kucisti_ike@yahoo.com

\begin{abstract}
Many factors cause difficulty class VII SMP 12 Surakarta 2014/2015 study mathematics. In addition to the abstract mathematical characteristics, other factors causing difficulty in learning mathematics that students could come from within the students themselves (internal) or from outside the student (external). This resulted in low interest and mathematics learning outcomes. One reason is the lack of teachers in the optimal use of props, the media and the right approach that can make students interested, aroused, quickly catching and easy to understand the material given. To overcome this problem is presented based trash props (APBS) GeoGebra software combined with a scientific approach to the study of mathematics. This budgets material is all around us, it is easy to get, easy to be pursued, easy to make, inexpensive and very familiar with the students. While the software GeoGebra is also a very simple application to be downloaded for free. The scientific approach is an approach to learning that are tailored to the curriculum in 2013 that made the students as a learning center. Results of this class action is the use of GeoGebra software budgets combined with a scientific approach can increase interest and student learning outcomes VIIH semester grade 2014/2015 transformation of matter.
\end{abstract}

Keywords: budgets, geogebra, siantifik approach, interest in learning,

\begin{abstract}
ABSTRAK
Banyak faktor yang menyebabkan kelas VII SMP 12 Surakarta 2014/2015, kesulitan belajar matematika. Selain karakteristik matematika abstrak, faktor lain yang menyebabkan kesulitan dalam belajar matematika bisa datang dari dalam siswa itu sendiri (internal) maupun dari luar siswa (eksternal). Hal ini mengakibatkan rendahnya hasil belajar matematika. Salah satu alasan adalah kurang optimalnya guru dalam penggunaan alat peraga, media dan pendekatan yang tepat yang bisa membuat siswa tertarik, terangsang, cepat menangkap dan mudah memahami materi yang diberikan. Untuk mengatasi masalah ini pembelajaran disajikan berdasarkan alat peraga APBS GeoGebra dikombinasikan dengan pendekatan ilmiah. Bahan alat peraga ini ada di sekitar siswa, mudah untuk mendapatkan, mudah untuk membuat, murah dan sangat
\end{abstract}


akrab dengan siswa. Sementara perangkat lunak GeoGebra juga aplikasi yang sangat sederhana untuk diunduh secara gratis. Pendekatan ilmiah adalah suatu pendekatan pembelajaran yang disesuaikan dengan kurikulum 2013 yang membuat siswa sebagai pusat pembelajaran. Hasil penelitian, penggunaan GeoGebra dikombinasikan dengan pendekatan ilmiah dapat meningkatkan minat dan hasil belajar siswa kelas VIIH tahun 2014/2015 materi transformasi.

Kata kunci: anggaran, GeoGebra, pendekatan siantifik, minat belajar

\section{PENDAHULUAN}

Matematika adalah pelajaran yang memiliki objek abstrak dan dibangun melalui proses penalaran deduktif, yaitu kebenaran suatu konsep diperoleh sebagai akbat logis dari kebenaran sebelumnya, sehingga keterkaitan antar konsep dalam matematika bersifat sangat kuat dan jelas (Depdiknas, 2004: 5). Dikarenakan sifat matematika yang abstrak, maka sampai saat ini matematika masih menjadi momok dalam proses pembelajaran di sekolah. Banyak siswa yang memiliki minat rendah dan tidak senang untuk belajar matematika. Bukti rendahnya hasil belajar matematika siswa dapat dilihat dari hasil tes pertama di semester genap tahun pelajaran 2014/ 2015 dari 26 siswa kelas VIIH hanya 12 siswa yang memenuhi KKM atau $46,15 \%$ siswa yang tuntas.

Ironisnya, matematika mempunyai kegunaan yang sangat penting dalam kehidupan seharihari. Disadari atau tidak kebermanfaatan matematika sangat berpengaruh dalam berbagai aspek utama seperti ekonomi, sosial, politik, kesehatan, teknologi dan pendidikan. Shodiq dalam makalahnya menyampaikan bahwa NRC (National Research Council, 1989:1) dari Amerika Serikat telah menyatakan pentingnya matematika dengan pernyataan : "Matematics is the key to opportunity.” Matematika adalah kunci ke arah peluang-peluang.

Media berasal dari kata "Medium” yang berasal dari bahasa latin "Medius” yang berarti “tengah" atau "sedang”. Pengertian media mengarah pada sesuatu yang mengantar/ meneruskan informasi (pesan) antara sumber (pemberi pesan) dan penerima pesan (Latuheru, 1988:9). Menurut EACT yang dikutip oleh Rohani (1997:2) “media adalah segala bentuk yang dipergunakan untuk proses penyaluran informasi”.Menurut McLuhan (dalam Sihkabuden, 1985:2) media merupakan suatu sarana atau channel sebagai perantara antara pemberi pesan kepada penerima pesan.

Dengan berpedoman pada pendapat di atas maka dapat disimpulkan bahwa media adalah suatu alat atau sarana atau perangkat. Dalam hal ini bisa berupa software atau hardware. Perangkat lunak (software) berisi pesan atau informasi pendidikan yang biasanya disajikan dengan menggunakan peralatan. Sedangkan peralatan atau perangkat keras (hardware) sendiri merupakan sarana untuk dapat menampilkan pesan yang terkandung.

Pembelajaran dapat diartikan sebagai upaya untuk membelajarkan pebelajar. Membelajarkan berarti usaha untuk membuat seseorang belajar. Dalam upaya pembelajaran terjadi komunikasi antara pebelajar dengan guru, pembelajar atau pengajar. Proses ini merupakan bagian proses komunikasi antar manusia (dalam hal ini adalah antara pebelajar dan pembelajar). Media pembelajaran adalah segala sesuatu yang dapat digunakan untuk 
menyalurkan pesan dari pengirim kepada penerima untuk menyampaikan materi yang yang diajarkan serta sarana komunikasi dari guru kepada siswa sehingga dapat merangsang pikiran, perasaan, perhatian dan minat yang menjurus kearah terjadinya proses belajar dengan tujuan untuk mencapai tujuan pembelajaran.

Alat peraga merupakan alat yang digunakan untuk membantu proses belajar mengajar yang berperan sebagai pendukung kegiatan belajar mengajar yang dilakukan oleh guru. Penggunaan alat peraga bertujuan untuk memberikan wujud riil terhadap bahan yang dibicarakan dalam materi pembelajaran. Alat peraga yang digunakan dalam proses belajar mengajar dalam garis besarnya memiliki faedah menambahkan kegiatan belajar siswa, menghemat waktu belajar, memberikan alasan yang wajar untuk belajar karena membangkitkan minat perhatian dan aktivitas siswa.

Menurut Nasution (1985: 100) "alat peraga adalah alat pembantu dalam mengajar agar efektif”. Pendapat lain dari pengertian alat peraga atau Audio-Visual Aids (AVA) adalah media yang pengajarannya berhubungan dengan indera pendengaran (Suhardi, 1978: 11). Sejalan dengan itu Sumadi (1972: 4) mengemukakan bahwa alat peraga atau AVA adalah alat untuk memberikan pelajaran atau yang dapat diamati melalui panca indera.

Secara umum alat peraga adalah saluran komunikasi atau perantara yang digunakan untuk membawa atau menyampaikan suatu pesan guna mencapai tujuan pengajaran. Alat peraga merupakan alat bantu atau penunjang yang digunakan oleh guru untuk menunjang proses belajar mengajar.

Ide pembuatan media ini berawal dari kegelisahan penulis saat melihat barang-barang bekas yang sudah tidak terpakai agar dapat lebih berguna. Alat peraga ini terbuat dari mika bening bekas pembungkus pakaian atau mainan dan karton bekas untuk membantu siswa dalam memahami konsep-konsep dan prinsip-prinsip transformasi dengan berbagai eksplorasi.

Multimedia berbasis komputer adalah media yang menggunakan komputer sebagai alat bantu (Wena, 2008: 203). Manfaat multimedia berbasis komputer menurut Mampuono (2010) adalah: a) proses pembelajaran lebih menarik, lebih interaktif, lebih mudah dipahami dan lebih menyenangkan, b) jumlah waktu mengajar dapat dikurangi, c) kualitas belajar siswa dapat ditingkatkan semaksimal mungkin, d) proses pembelajaran dan belajar dapat dilakukan kapan saja dan dimana saja, e) sikap (minat) belajar siswa dapat ditingkatkan.

Berdasarkan uraian di atas dapat dikatakan bahwa multimedia berbasis komputer adalah media yang menggunakan komputer sebagai alat bantu dengan memperhatikan parameter multimedia yang baik. Sedangkan geogebra adalah software komputer yang dinamis yang dapat digunakan sebagai alat bantu dalam pembelajaran matematika. Software ini dikembangkan untuk proses belajar mengajar matematika di sekolah oleh Markus Hohenwarter di Universitas Florida Atlantic. Terdapat paling tidak tiga (3) kegunaan geogebra, yaitu sebagai: media pembelajaran matematika, sebagai pembuat bahan ajar, dan menyelesaikan soal-soal matematika.

Pembelajaran dengan pendekatan saintifik adalah pembelajaran yang terdiri atas kegiatan mengamati (untuk mengidentifikasi hal-hal yang ingin diketahui), merumuskan pertanyaan (dan merumuskan hipotesis), mencoba/mengumpulkan data (informasi) dengan berbagai teknik, mengasosiasi/ menganalisis/mengolah data (informasi) dan menarik kesimpulan serta 
mengkomunikasikan hasil yang terdiri dari kesimpulan untuk memperoleh pengetahuan, keterampilan dan sikap. Langkah-langkah tersebut dapat dilanjutkan dengan kegiatan mencipta. (http://www.salamedukasi.com/2014/06/pengertiandefinisi-pendekatan-aintifik. $\underline{\mathrm{html}}$.

Dapat disimpulkan pendekatan saintifik adalah suatu pendekatan yang menjadikan siswa sebagai pusat pembelajaran. Langkah-langkah pendekatan saintifik dalam proses pembelajaran meliputi $5 \mathrm{M}$ dan $1 \mathrm{M}$, yaitu: Mengamati, Menanya, Menggali informasi (mencoba), Menganalisis (menyimpulkan), Mengomunikasikan, dan Mencipta.

Hurlock (1993) mengemukakan bahwa minat merupakan hasil dari pengalaman belajar, bukan hasil bawaan sejak lahir. Hurlock (1993) juga menekankan pentingnya minat, bahwa minat menjadi sumber motivasi kuat bagi seseorang untuk belajar, minat juga mempengaruhi bentuk dan intensitas aspirasi seseorang dan minat juga menambah kegembiraan pada setiap kegiatan yang ditekuni seseorang. Pintrich dan Schunk (1996) juga menyebutkan bahwa minat merupakan sebuah aspek penting dari motivasi yang mempengaruhi perhatian, belajar, berpikir dan prestasi. Sedangkan belajar matematika menurut Sutama (2011: 25) proses belajar merupakan proses komunikasi yang melibatkan: (1) komponen pengirim pesan (guru) matematika, (2) komponen penerima pesan (siswa), dan (3) komponen pesan itu sendiri yang berupa materi ajar matematika.

Berdasarkan uraian di atas yang dimaksud dengan minat belajar matematika adalah gejala psikologis yang menunjukan pemusatan perhatian dalam belajar matematika sebab adanya perasaan senang siswa terhadap kegiatan tersebut. Maksudnya adanya pemusatan perhatian siswa dalam belajar matematika yang didahului oleh perasaan senang terhadap belajar matematika tersebut. Indikator minat belajar matematika dapat dilihat dari: 1) ketepatan waktu menyelesaikan tugas, 2) keaktifan dalam tanya jawab, 3) kerja sama dalam kelompok.

Hasil belajar matematika menurut Maier (1996: 103) adalah sesuatu yang diperoleh dari kegiatan pembelajaran matematika yang diberikan dengan angka atau huruf. Hasil belajar matematika yang dimaksud dapat dinyatakan dalam nilai-nilai dengan rentang 0 sampai dengan 100, atau dengan menggunakan huruf seperti A, B, C, D, dan E. Dari hasil belajar matematika dapat dijadikan dasar untuk menentukan prestasi belajar matematika. Jadi hasil belajar matematika adalah perolehan yang di dapat dari hasil pembelajaran matematika melalui penilaian pembelajaran yang dapat dituangkan dengan angka ataupun huruf.

Berdasarkan uraian di atas, tujuan penelitian ini untuk meningkatkan minat dan hasil belajar matematika materi transformasi kelas VIIH semester genap tahun 2014/ 2015 SMPN 12 Surakarta dengan pemanfaatan Alat Peraga Berbasis Sampah (APBS) dan geogebra berbasis pendekatan saintifik.

\section{METODE}

Penelitian ini dilaksanakan pada semester genap tahun pelajaran 2014/2015 yaitu mulai bulan januari s.d. bulan April 2015. Penelitian ini dilaksanakan di SMPN 12 Surakarta yang terletak di Jalan Ahmad Yani no. 370 Surakarta. Pemilihan tempat penelitian ini didasari oleh tempat kerja peneliti sehingga proses penelitian dapat berjalan dengan efektif.

Sebagai subjek dalam penelitian tindakan sekolah ini adalah peserta didik kelas VIIH SMPN 12 Surakarta sejumlah 26 orang, yang terdiri dari 12 peserta didik laki-laki dan 14 
peserta didik perempuan. Objek penelitian ini ada empat (5) variabel yaitu: dua (2) variabel yang diteliti dan satu (3) variabel tindakan. Variabel yang diteliti meliputi: 1) minat belajar matematika materi transformasi peserta didik kelas VIIH SMPN 12 Surakarta pada semester genap tahun pelajaran 2014/2015; dan 2) hasil belajar matematika peserta didik kelas VIIH SMPN 12 Surakarta pada semester genap tahun pelajaran 2014/2015. Sedangkan variabel tindakannya adalah 1) pemanfaatan APBS; 2) pemanfaatan media geogebra; dan 3) pendekatan saintifik.

Tindakan dalam penelitian ini dilakukan dengan dua (2) cara, yaitu pemanfaatan APBS dan geogebra dengan pendekatan saintifik menggunakan 1 LKS tiap kelompok sebagai tindakan pada siklus 1, dan pemanfaatan APBS dan geogebra dengan pendekatan saintifik menggunakan LKS sejumlah anggota kelompok sebagai tindakan pada siklus 2.

Berdasarkan asal sumber datanya, dalam penelitian terdiri dari dua (2) sumber data, yaitu: 1) sumber data yang berasal langsung dari subjek yang diteliti, dalam penelitian ini adalah data hasil belajar matematika peserta didik kelas VIIH pada semester genap tahun pelajaran 2014/2015, kemudian disebut data primer; 2) sumber data yang berasal tidak langsung dari subjek yang diteliti, dalam penelitian ini adalah data minat belajar matematika peserta didik kelas VIIH pada semester genap tahun pelajaran 2014/2015, kemudian disebut data sekunder. Data primer peroleh langsung dari subyek yang diteliti melalui tes tertulis, sedangkan data sekunder diperoleh dari observasi dan kolaborasi dengan teman sejawat.

Dalam penelitian ini, data minat belajar matematika peserta didik kelas VIIH pada semester genap tahun pelajaran 2014/2015 kondisi awal diperoleh dengan menggunakan teknik dokumentasi yang alatnya berupa dokumen buku catatan tentang minat belajar matematika peserta didik kelas VIIH pada semester genap tahun pelajaran 2014/2015 kondisi awal.

Sedangkan data hasil belajar matematika peserta didik kelas VIIH pada semester genap tahun pelajaran 2014/2015 kondisi awal diperoleh dengan menggunakan teknik dokumentasi yang alatnya berupa hasil tes sebelum siklus. Adapun data minat minat belajar matematika peserta didik kelas VIIH pada semester genap tahun pelajaran 2014/2015 siklus 1 dan 2 diperoleh dengan menggunakan teknik observasi yang alatnya berupa lembar observasi. Untuk data hasil belajar matematika peserta didik kelas VIIH pada semester genap tahun pelajaran 2014/2015 siklus 1 dan 2 diperoleh dengan menggunakan teknik tes tertulis yang alatnya berupa butir soal tes tertulis.

Data Minat peserta didik belajar matematika diperoleh melalui observasi, maka supaya data tersebut valid perlu melibatkan observer lain atau berkolaborasi dengan teman sejawat. Data hasil belajar matematika diperoleh melalui tes tertulis dengan alat yang disebut butir soal tes tertulis. Oleh sebab itu supaya data ini valid, maka dilakukan validitas isi atau content validity yaitu dengan cara membuat kisi-kisi soal. Kisi-kisi tersebut dibuat agar materi pada soal tersebut mengelompok pada bahasan tertentu, dan atau materi soal sesuai dengan kurikulum atau aturan yang berlaku. Bukti dari validasi isi atau content validity adalah berupa lampiran kisi-kisi. 
Cara menganalisis data dengan menggunakan diskriptif - komparatif yang dilanjutkan transformasi. Adapun yang dimaksud diskriptif - komparatif adalah membandingkan data kondisi awal dengan data siklus 1 , data siklus 1 dibandingkan dengan data siklus 2, dan data kondisi awal dibandingkan dengan data siklus 2. Sedangkan yang dimaksud transformasi adalah membuat simpulan berdasarkan diskriptif - komparatif, kemudian memberi ulasan atas simpulan tersebut dan menentukan action plan (tindak lanjut) siklus berikutnya.

Indikator kinerja adalah target yang dicapai. Ada dua (2) target yang dicapai yaitu: 1) pada siklus 2 lebih dari 20 peserta didik (77\%) atau sebagian besar peserta didik mempunyai minat belajar matematika tinggi, 2) target yang dicapai pada siklus 2 hasil belajar matematika minimal 20 orang (76,90\%) peserta didik tuntas atau memenuhi KKM yaitu 2,67 skala 4 atau 67 skala 100.

\section{HASIL DAN PEMBAHASAN}

Di kelas VIIH SMPN 12 Surakarta minat dalam belajar matematika masih rendah. Dari hasil kajian terhadap dokumentasi catatan peserta didik diperoleh dari 26 peserta didik di kelas VIIH ketepatan menyelesaikan tugas, keaktifan belajar dalam kelas, dan kemampuan bekerja sama dalam kelompok para peserta didik sebagian besar masih rendah. Pada kondisi awal, berdasarkan hasil tes pertama dari 26 peserta didik kelas VIIH SMPN 12 Surakarta, tercatat hanya 12 peserta didik yang tuntas dalam belajar, yang artinya baru 46,15\% peserta didik yang tuntas.

Hasil pengamatan terhadap minat belajar matematika di SMPN 12 Surakarta pada siklus 1 dari hasil observasi yang peneliti lakukan adalah bahwa, dari 26 peserta didik kelas VIIH SMPN 12 Surakarta, 19 peserta didik (73,08\%) sudah dapat menunjukkan minat yang tinggi, sedangkan sisanya 7 orang (26,92\%) menunjukkan minat rendah. Pengamatan terhadap minat dilihat dari tiga indikator, yakni ketepatan menyelesaikan tugas, keaktifan belajar dalam kelas, dan kemampuan bekerja sama dalam kelompok.

Gambaran di atas, nampak kerja sama dalam kelompok dan minat mengerjakan tugas sudah terjalin, meskipun masih ada peserta didik yang belum menunjukkan minat belajar matematika. Hal ini terjadi karena peserta didik bekerja dalam kelompok besar sehingga kerja sama, ketepatan mengerjakan tugas, dan keaktifan dalam belajar belum tercipta secara optimal.

Hasil belajar peserta didik VIIH setelah menggunakan pemanfaatan APBS dan geogebra dengan pendekatan saintifik, berdasarkan hasil tes siklus pertama, dari 26 peserta didik yang tuntas adalah 17 peserta didik atau 62,96\%, sisanya 9 peserta didik atau 57,14\% belum tuntas.

Hasil transformasi pada siklus 1 yang telah dilaksanakan dapat dituangkan dalam tabel berikut. 
Tabel 1.Tabel Transformasi Minat Belajar Matematika Siklus 1

\begin{tabular}{|c|c|c|c|}
\hline No. & Kondisi Awal & Siklus 1 & Transformasi \\
\hline 1. & $\begin{array}{l}\text { Minat belajar peserta didik } \\
\text { sebelum siklus hanya separuh } \\
\text { peserta didik tinggi }\end{array}$ & $\begin{array}{l}\text { Minat belajar peserta didik } \\
\text { setelah siklus } 1 \text { sudah lebih } \\
\text { dari tujuh puluh persen } \\
\text { peserta didik menunjukkan } \\
\text { minat yang tinggi }\end{array}$ & $\begin{array}{l}\text { Melalui penerapan pemanfaatan } A P B S \\
\text { dan geogebra dengan pendekatan } \\
\text { saintifik dari kondisi awal ke siklus } \\
1 \text { meningkat dari separuh tinggi ke } \\
\text { lebih dari tujuh puluh persen dari } \\
\text { jumlah peserta didik menunjukkan } \\
\text { minat belajar matematika tinggi }\end{array}$ \\
\hline
\end{tabular}

Hasil transformasi pada siklus 1 yang telah dilaksanakan dapat dituangkan dalam tabel berikut.

Tabel 2.Tabel Transformasi Hasil Belajar Matematika Siklus 1

\begin{tabular}{|c|c|c|c|c|c|}
\hline No. & \multicolumn{2}{|c|}{$\begin{array}{l}\text { Hasil Belajar Matematika } \\
\text { Kondisi Awal }\end{array}$} & \multicolumn{2}{|c|}{$\begin{array}{c}\text { Hasil Belajar } \\
\text { Matematika pada Siklus } \\
1\end{array}$} & $\begin{array}{c}\text { Deskriptif Komparatif Hasil Belajar } \\
\text { Matematika }\end{array}$ \\
\hline \multirow{2}{*}{1.} & tuntas & $\begin{array}{l}12 \text { peserta } \\
\text { didik } \\
(46,15 \%)\end{array}$ & tuntas & $\begin{array}{l}17 \text { peserta } \\
\text { didik } \\
(62,96 \%)\end{array}$ & \multirow{2}{*}{$\begin{array}{l}\text { Melalui penerapan pemanfaatan APBS } \\
\text { dan geogebra dengan pendekatan } \\
\text { saintifik dari kondisi awal ke siklus } 1 \\
\text { peserta didik yang tuntas meningkat } \\
\text { sebesar } 16,81 \% \text { (5 orang) }\end{array}$} \\
\hline & $\begin{array}{l}\text { belum } \\
\text { tuntas }\end{array}$ & $\begin{array}{l}14 \text { peserta } \\
\text { didik } \\
(53,85 \%)\end{array}$ & $\begin{array}{l}\text { Belum } \\
\text { tuntas }\end{array}$ & $\begin{array}{l}9 \text { peserta } \\
\text { didik } \\
(37,04 \%)\end{array}$ & \\
\hline
\end{tabular}

Hasil pengamatan terhadap minat belajar matematika di SMPN 12 Surakarta pada siklus 2 dari hasil observasi yang peneliti lakukan adalah bahwa, dari 26 peserta didik kelas VIIH SMPN 12 Surakarta, 22 peserta didik (84,62\%) sudah dapat menunjukkan minat yang tinggi, sedangkan sisanya 4 orang $(15,38 \%)$ menunjukkan minat rendah. Pengamatan terhadap minat dilihat dari tiga indikator, yakni ketepatan menyelesaikan tugas, keaktifan belajar dalam kelas, dan kemampuan bekerja sama dalam kelompok.

Hasil belajar peserta didik VIIH setelah menggunakan pemanfaatan APBS dan geogebra dengan pendekatan saintifik, berdasarkan hasil tes siklus dua, dari 26 peserta didik yang tuntas adalah 22 peserta didik atau 84,62\%, sisanya 4 peserta didik atau 15,38\% belum tuntas.

Hasil transformasi pada siklus 2 yang telah dilaksanakan dapat dituangkan dalam tabel berikut.

Tabel 3.Tabel Transformasi Minat Belajar Matematika Siklus 2

\begin{tabular}{|c|c|c|c|}
\hline No. & Kondisi Awal & Siklus 2 & Transformasi \\
\hline 1. & $\begin{array}{l}\text { Minat belajar peserta didik } \\
\text { sebelum siklus hanya separuh } \\
\text { peserta didik tinggi }\end{array}$ & $\begin{array}{l}\text { Minat belajar peserta di- } \\
\text { dik setelah siklus } 2 \text { sudah } \\
\text { lebih dari delapan pu- } \\
\text { luh persen peserta didik } \\
\text { menunjukkan minat yang } \\
\text { tinggi }\end{array}$ & $\begin{array}{l}\text { Melalui penerapan pemanfaatan } A P B S \\
\text { dan geogebra dengan pendekatan sain- } \\
\text { tifik dari kondisi awal ke siklus } 2 \text { mening- } \\
\text { kat dari separuh tinggi ke lebih dari } \\
\text { delapan puluh persen dari jumlah peserta } \\
\text { didik menunjukkan minat belajar matem- } \\
\text { atika tinggi }\end{array}$ \\
\hline
\end{tabular}


Hasil transformasi pada siklus 2 yang telah dilaksanakan dapat dituangkan dalam tabel berikut.

Tabel 4. Tabel Transformasi Hasil Belajar Matematika Siklus 2

\begin{tabular}{|c|c|c|c|c|c|}
\hline No. & \multicolumn{2}{|c|}{$\begin{array}{c}\text { Hasil Belajar } \\
\text { Matematika Kondisi } \\
\text { Awal } \\
\end{array}$} & \multicolumn{2}{|c|}{$\begin{array}{c}\text { Hasil Belajar } \\
\text { Matematika pada Siklus } \\
2 \\
\end{array}$} & $\begin{array}{c}\text { Deskriptif Komparatif Hasil } \\
\text { Belajar Matematika }\end{array}$ \\
\hline \multirow{2}{*}{1.} & tuntas & $\begin{array}{l}12 \text { peserta } \\
\text { didik } \\
(46,15 \%)\end{array}$ & tuntas & $\begin{array}{l}22 \text { peserta } \\
\text { didik } \\
(84,62 \%)\end{array}$ & \multirow{2}{*}{$\begin{array}{l}\text { Melalui penerapan pemanfaatan } \\
\text { APBS dan geogebra dengan } \\
\text { pendekatan saintifik dari kondis } \\
\text { awal ke siklus } 2 \text { peserta didik } \\
\text { yang tuntas meningkat sebesar } \\
38,47 \% \text { (10 orang) }\end{array}$} \\
\hline & $\begin{array}{l}\text { belum } \\
\text { tuntas }\end{array}$ & $\begin{array}{l}14 \text { peserta } \\
\text { didik } \\
(53,85 \%)\end{array}$ & $\begin{array}{l}\text { Belum } \\
\text { tuntas }\end{array}$ & $\begin{array}{l}4 \text { peserta } \\
\text { didik } \\
(15,38 \%)\end{array}$ & \\
\hline
\end{tabular}

Hasil pelaksanaan penelitian tentang minat belajar matematika peserta didik kelas VIIH SMPN 12 Surakarta tahun pelajaran 2014/ 2015 siklus 1 dan 2 yang telah dilaksanakan dapat dituangkan dalam tabel berikut.

Tabel 5.Tabel Pembahasan Minat Belajar Matematika

\begin{tabular}{|c|c|c|c|c|}
\hline No. & Kondisi Awal & Siklus 1 & $\begin{array}{c}\text { Siklus 2/ } \\
\text { Kondisi Akhir }\end{array}$ & Transformasi \\
\hline 1. & $\begin{array}{l}\text { Minat belajar peserta } \\
\text { didik sebelum siklus } \\
1 \text { hanya separuh dari } \\
\text { peserta didik yang } \\
\text { berminat tinggi }\end{array}$ & $\begin{array}{l}\text { Minat belajar peserta } \\
\text { didik setelah siklus } \\
1 \text { sudah lebih dari } \\
\text { tujuh puluh persen } \\
\text { jumlah peserta didik } \\
\text { menunjukkan minat } \\
\text { yang tinggi }\end{array}$ & $\begin{array}{lr}\text { Minat } & \text { belajar } \\
\text { peserta } & \text { didik } \\
\text { setelah } & \text { siklus } 2 \\
\text { sudah } & \text { sebagian } \\
\text { besar peserta } & \text { didik (lebih dari } \\
\text { 80\%) dari jumlah } \\
\text { peserta didik } \\
\text { menunjuk u a n } \\
\text { minat yang tinggi }\end{array}$ & $\begin{array}{lr}\text { Melalui } & \text { penerapan } \\
\text { pemanfaatan } & \text { APBS } \\
\text { dan geogebra dengan } \\
\text { pendekatan saintifik dari } \\
\text { kondisi awal ke siklus } \\
2 \text { meningkat dari hanya } \\
\text { separuh peserta didik } \\
\text { berminat tinggi ke sebagian } \\
\text { besar peserta didik } \\
\text { menunjukkan minat belajar } \\
\text { matematika tinggi }\end{array}$ \\
\hline
\end{tabular}

Jadi dapat dikatakan bahwa melalui penerapan pemanfaatan APBS dan geogebra dengan pendekatan saintifik dapat meningkatkan minat belajar matematika peserta didi kelas VIIH SMPN 12 Surakarta tahun pelajaran 2014/ 2015.

Hasil pelaksanaan penelitian tentang hasil belajar matematika peserta didik kelas VIIH SMPN 12 Surakarta tahun pelajaran 2014/ 2015 siklus 1 dan 2 yang telah dilaksanakan dapat dituangkan dalam tabel berikut. 


$\begin{array}{lcccc}\text { No. } & \text { Hasil Belajar } & \text { Hasil Belajar } & \text { Hasil Belajar } & \text { Transformasi dari Kondisi } \\ \text { Kondisi Awal } & \text { Siklus 1 } & \text { Kondisi Akhir } & \text { Awal ke Kondisi Akhir }\end{array}$

\begin{tabular}{|c|c|c|c|c|}
\hline \multirow{2}{*}{1.} & $\begin{array}{c}\text { Tuntas=12 } \\
\text { peserta didik } \\
(46,15 \%)\end{array}$ & $\begin{array}{c}\text { Tuntas=17 } \\
\text { peserta didik } \\
(62,96 \%)\end{array}$ & $\begin{array}{l}\text { Tuntas=22 } \\
(84,62 \%)\end{array}$ & \multirow{2}{*}{$\begin{array}{l}\text { Melalui penerapan pemanfaatan } \\
\text { APBS dan geogebra dengan } \\
\text { pendekatan saintifik dari kondisi } \\
\text { awal ke siklus } 2 \text { peserta didik } \\
\text { yang tuntas meningkat sebesar } \\
38,47 \% \text { (10 orang) }\end{array}$} \\
\hline & $\begin{array}{c}\text { Belum } \\
\text { tuntas=14 } \\
\text { peserta didik } \\
(53,5 \%)\end{array}$ & $\begin{array}{c}\text { Belum tuntas=9 } \\
\text { peserta didik } \\
(37,04 \%)\end{array}$ & $\begin{array}{c}\text { Belum } \\
\text { tuntas }=4 \text { peserta } \\
\text { didik }(15,38 \%)\end{array}$ & \\
\hline
\end{tabular}

Jadi dapat dikatakan bahwa melalui penerapan pemanfaatan APBS dan geogebra dengan pendekatan saintifik dapat meningkatkan hasil belajar matematika peserta didik kelas VIIH SMPN 12 Surakarta tahun pelajaran 2014/ 2015. Berdasarkan hasil tindakan pada siklus 1 dan siklus 2 dapat dikatakan bahwa:

a. Melalui penerapan pemanfaatan APBS dan geogebra dengan pendekatan saintifik dapat meningkatkan minat belajar matematika peserta didik kelas VIIH SMPN 12 Surakarta tahun pelajaran 2014/ 2015.

b. Melalui penerapan pemanfaatan APBS dan geogebra dengan pendekatan saintifik dapat meningkatkan hasil belajar matematika peserta didik kelas VIIH SMPN 12 Surakarta tahun pelajaran 2014/ 2015.

c. Melalui penerapan pemanfaatan $A P B S$ dan geogebra dengan pendekatan saintifik dapat meningkatkan minat dan hasil belajar matematika peserta didik kelas VIIH SMPN 12 Surakarta tahun pelajaran 2014/ 2015.

\section{SIMPULAN}

Berdasarkan hasil dan pembahasan dapat disimpulkan bahwa: (1) Melalui penerapan pemanfaatan APBS dan geogebra dengan pendekatan saintifik dapat meningkatkan minat belajar matematika peserta didik kelas VIIH SMPN 12 Surakarta tahun pelajaran 2014/ 2015. (2) Melalui Melalui penerapan pemanfaatan APBS dan geogebra dengan pendekatan saintifik dapat meningkatkan hasil belajar matematika peserta didik kelas VIIH SMPN 12 Surakarta tahun pelajaran 2014/ 2015. (3) Melalui penerapan pemanfaatan APBS dan geogebra dengan pendekatan saintifik dapat meningkatkan minat dan hasil belajar matematika peserta didik kelas VIIH SMPN 12 Surakarta tahun pelajaran 2014/ 2015. 
ISSN: 1907-4034

\section{DAFTAR PUSTAKA}

Arikunto, Suharsimi. 2006. Penelitian Tindakan Kelas. Jakarta: PT Bumi Aksara

Maier, Hermann. 1995. Kompendium Didaktik Matematika. Bandung: Remaja Rosdakarya

Mampuono. 2010. “Multimedia Pembelajaran”. Semarang: LPMP

Mulyasa, E. 2004. Menjadi Guru Profesional. Bandung: Remaja Rosdakarya

Sanjaya, Wina. 2010. Penelitian Tindakan Kelas. Jakarta: Kencana Prenada Media Group

Sardiman. 2003. Interaksi dan Motivasi Belajar Mengajar. Jakarta: Pt. Grafindo Persada

Sodiq, Fadjar. 2009. “Pentingnya Matematika dalam Kehidupan”. Yogjakarta:LIMAS PPPPTK Matematika

Siberman, Mel. 2009. Active Learning: 101 Strategi Pembelajaran Aktif. Yogyakarta: YAPPENDIS

Sudaryanto. 1996. Perpustakaan sekolah sebagai sarana pengembangan minat dan kegemaran membaca murid. Disajikan pada LokakaryaPengembangan Minat Baca dan Kegemaran Membaca Murid PendidikanDasar.

Sutama. 2010. Penelitian Tindakan Teori dan Praktek dalam PTK, PTS, dan PTBK. Surakarta: Muhammadiyah University Pres.

Sutama. 2011. Pengelolaan Pembelajaran Matematika, Berbasis Aptitude Treatment Interaction. Surakarta: Muhammadiyah University Pres.

Uno, B. Hamzah. 2007.Model Pembelajaran Ciptakan Proses Belajar Mengajar yang Kreatif dan Efektif. Jakarta: Bumi Aksara

Wena, Made. 2009. Strategi Pembelajaran Inovatif Kontemporer. Jakarta: PT. Bumi Aksara

Whiteringten HC. 1991. Psikologi Pendidikan . Jakarta: Rineka Ilmu.Yunus. 1992.

Widada. 2010. Mudah Membuat Media Pembelajaran Multimedia Interaktif untuk Guru dan Profesional. Yogyakarta: Pustaka Widyatama

WWW.Manfaatmediapembelajaranof .com, diakses tanggal 4 November 2015

http://www.salamedukasi.com/2014/06/pengertiandefinisi-pendekatan-saintifik.html, diakses tanggal 5 November 2015 